\title{
Impact of Hypoxia on the Community Structure of Benthic Macroinvertebrates of Lagos Lagoon, Nigeria
}

\section{NKWOJI JOSEPH AHAMEFULA}

\author{
Department of Marine Sciences, University of Lagos, Nigeria
}

E-mail:jnkwoji@unilag.edu.ng

\begin{abstract}
Study of the Lagos lagoon was conducted for two years to investigate the impact of hypoxia on the benthic macroinvertebrates. Water and benthic samples were collected monthly along the study stretch and analysed in a standard laboratory. Temporal variation in water physico-chemistry was largely controlled by rainfall pattern while the spatial variation was influenced by proximity to the Harbour as well as the pollution sources and types. A total of 3,159 individuals comprising three phyla, five classes, nineteen families and twenty three species were recorded. Iddo I, Iddo II, Ogudu and Agboyi study stations recorded very low individuals, but relatively high number of polychaetes. Benthic macro- invertebrate community was dominated by the molluscs. Margalef's index of species richness ranged from 0.79 to 2.57 while Shannon-Wiener index ranged from 0.40 to 2.19. Species evenness index ranged from 0.29 to 0.80 . There was generally low biodiversity indicating the stressed nature of the study area. () JASEM
\end{abstract}

\section{http://dx.doi.org/10.4314/jasem.v20i1.15}

KEYWORDS: Hypoxia, diversity, benthic, macroinvertebrates, lagoon.

\section{Introduction}

The discharge of untreated sewage and other organic forms of pollution have been a major source of pollution of the Lagos lagoon in Lagos, Nigeria. The microbial degradation of the sewage results in the depletion of the dissolved oxygen in the water and this impacts on the aquatic biota. Oyenekan (1987) stated that the healthy nature or pollution level of an aquatic ecosystem can be determined by the success or otherwise of the zoobenthos of that ecosystem. The high biochemical oxygen demand of microbes in this water translates into low dissolved oxygen. This has its major detrimental impacts on the chemistry of the water and sediment and on the respiratory activities of aerobic aquatic biota. The sedentary nature of the macro invertebrates makes them very vulnerable.

Benthic macroinvertebrates which are spineless aquatic fauna inhabiting the bottom, constitute an important part of the aquatic trophic relationship. Many of them feed on algae and bacteria, which are on the lower end of the food chain (Nystrom et al., 1996). Some shred and eat leaves and other organic matter that enters the water. As a result of their abundance and critical position in the aquatic food chain, the benthic macroinvertebrates plays a major role in the natural flow of energy and nutrients (Stockly et al., 1998). As they die, they decay, releasing nutrients that are reused by aquatic plants and animals in the trophic levels. In view of this, they can be used to evaluate the health of the aquatic ecosystem.

Lagos lagoon has received a remarkable research attention and quite a number of published information are available for different aspects of the hydrobiology and physico-chemical characteristics Early works on the macrobenthic fauna of the Lagos lagoon were on genus Pachymelania (Oyenekan, 1989) and Iphigenia truncata (Yoloye and Adegoke, 1977). Other works on benthic macroinvertebrates include the reproductive and population dynamics of Capitella capitata (Oyenekan, 1983), and the temporal variability of benthic macrofauna of the Lagoon and Harbour (Brown and Oyenekan, 1998). The environmental consequences of pollution on the Lagos lagoon has also been highlighted (Ekundayo, 1977). Akpata and Ekundayo (1978) worked on the faecal pollution of the Lagos Lagoon and reported low dissolved oxygen at the pollution point sources, while Nwankwo (1994) studied the hydrochemical properties of some benthic diatoms of a sewage disposal site at Iddo along the Lagos lagoon.

Adeniyi (1980) investigated the microbial decomposition of faeces in the Lagos lagoon and reiterated that the continuous monitoring of the sewage disposal site was necessary to evaluate any changing environmental condition in the station that 
may induce bloom of nuisance species. Ajao and Fagade (1990) worked on the seasonal and spatial distribution of the population of the polychaete, Capitella capitata in Lagos lagoon and recorded that the abundance of this polychaete was influenced by sediment type, organic content of the sediment and the sediment metals and hydrocarbon content of the sediment. Edokpayi and Nkwoji (2007) worked on the physico-chemical and macrobenthic invertebrate characteristics of a sewage dumpsite along the bank of Lagos lagoon and recorded a relatively high abundance of the polychaete of the family, Nereidae in the station closest to the sewage dump. This present study pays greater attention to the impact of low oxygen on the distribution, abundance and diversity of benthic macroinvertebrates west of Lagos lagoon, Nigeria.

\section{MATERIALS AND METHODS}

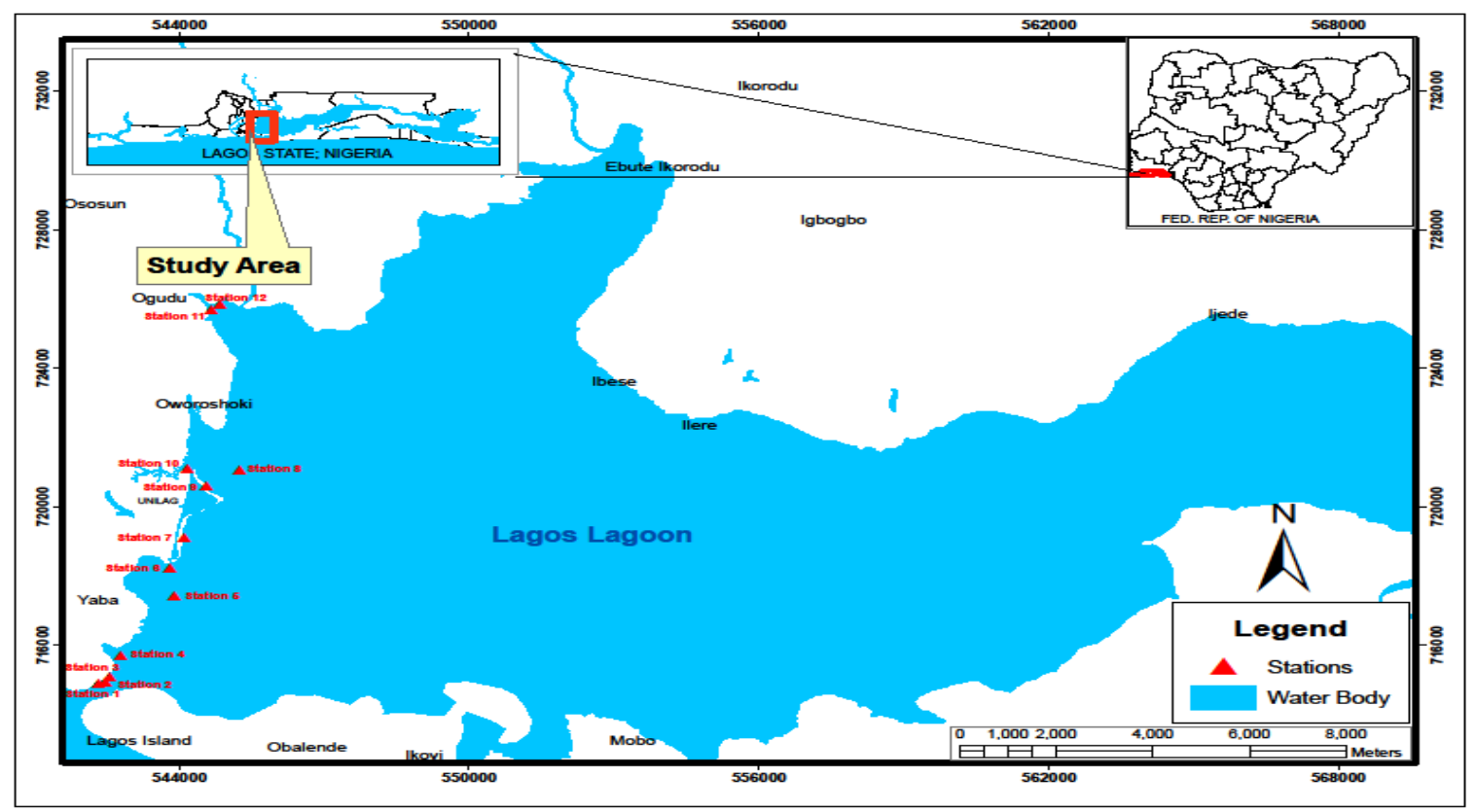

Figure 1: Map of Lagos lagoon showing the study stations

Collection of Samples: Monthly sampling for water was conducted for twenty four months at the twelve stations between the hours of 0800 and 1200. Bottom water samples were collected with $1 \mathrm{dm}^{3}$ Hydrobios bottom water sampler at each study station, with motorized boat, stored in a labeled container and transported to the laboratory where it was stored in the refrigerator at the temperature of $-5^{\circ} \mathrm{C}$ prior to further analyses. A $250 \mathrm{ml}$ dissolved oxygen bottle was used to collect water sample at each study station for dissolved oxygen estimation using iodometric
The study area is the western part of Lagos lagoon (Figure 1). The lagoon is located between latitude $6^{\circ}$ $26^{\prime}$ and $6^{\circ} 38^{\prime} \mathrm{N}$, longitude $3^{\circ} 23^{\prime}$ and $3^{\circ} 43^{\prime} \mathrm{E}$. It extends eastwards for about $200 \mathrm{~km}$ from the Nigerian-Benin Republic border to the western limit of the Transgressive Mud Coast covering an area of about $208 \mathrm{~km}^{2}$ (FAO, 1969). The lagoon sediments range between mud, sandy mud, muddy sand, and sand (Ajao and Fagade, 1990) and has a defined salinity gradient, linked with the rainfall pattern (Nwankwo and Akinsoji, 1992). Twelve sampling stations selected for this study were based on their importance as sources of different forms of contaminants into the lagoon. The stations stretch for about 9.5 miles $(15.29 \mathrm{~km})$ in length between Iddo and Agboyi axis of the lagoon. The spatial distance between sampling stations is about 0.75 miles (1.2 $\mathrm{km})$. Abule-Agege study station served as control because it is relatively distanced from anthropogenic activities. Locations of the stations were determined with the aid of the Global Positioning System (GPS)
Winkler's method. In situ multi-meter kits were employed in determining such parameters like temperature, salinity, turbidity, $\mathrm{pH}$ and conductivity. The nitrates, phosphates, and sulphates were determined using the Hach Spectrophotometer. Such parameters in the water like total suspended solids, biochemical oxygen demand, chemical oxygen demand, and iron were determined in the laboratory following APHA (1998). 
Benthic samples were collected concurrently using a Van-veen grab. At each study station, two grab hauls were sieved, fixed and labeled for macrobenthic fauna analysis while one grab haul was collected in a polyethene bag, labeled and stored at $-5^{0} \mathrm{C}$ for sediment grain size analysis.

Measurement of Physico-chemical Characteristics: Subsurface water temperature was measured in situ using the mercury-in-glass thermometer. Other physico-chemical characteristics of the water samples were analysed in the wet laboratory of the Nigerian Institute for Oceanography and Marine Research (NIOMR), using standard methods. Dissolved oxygen was analysed iodometrically after fixing with of Manganese Sulphate $\left(\mathrm{MnSO}_{4}\right)$ and Potassium Iodide (KI) respectively.

Benthic Macrofauna Analyses: Sieving and fixing for the benthic macroinvertebrates were conducted in situ with $0.55 \mathrm{~mm}$ mesh size sieve and $10 \%$ formalin respectively. Treatment and sorting of pure samples were conducted at the Benthic Ecology Laboratory, Department of Marine Sciences, University of Lagos. Relevant texts (Olaniyan, 1968; Yankson and Kendall, 2001; Zar, 1984) were used for identification. SPSS 11.0 Window application and Microsoft Excel were used for the biostatistical analyses. Data processing involved the calculation of biological indices such as Margalef's index for species richness, Shannon-Wiener and Simpson's indices for species diversity, and the Equitability index for evenness of the community:

Margalef's Index: This is a species richness index and was used to measure the diversity in the community structure. The equation below was

applied in the calculation: $d=\frac{S-1}{\ln N}$

Where: $d=$ Species richness index. $S=$ Number of species in a population ; $\mathrm{N}=$ Total number of individuals in $\mathrm{S}$ species

Shannon-Wiener Diversity Index: This is a measure of faunal diversity (Ogbeibu, 2005). It usually indicates the degree of uncertainty involved in predicting the species identified of randomly selected individuals. It is calculated using the following equation:

$$
\mathrm{H}^{\prime}=-\sum_{i=1}^{R} P i \ln P i
$$

Where: $\mathrm{H}^{\prime}=$ Shannon and Wiener diversity Index $i=$ Counts denoting the ith species ranging from $1-$ $\mathrm{R} \quad P i=$ Proportion that the ith species represents in terms of numbers of individuals with respect to the total number of individuals in the sampling space as whole.

Species Equitability: Species evenness or equitability was used to calculate how evenly the species are distributed in a community. It was determined by the equation: $J=\frac{H^{\prime}}{H^{\prime} \max }$

Where: $\mathbf{J}=$ Equitability Index $\quad \mathrm{H}^{\prime}=$ Shannon-Weiner index

\section{RESULTS AND DISCUSSION}

The summary of the physico-chemical characteristics of the water samples in the study stations for the period of study is shown in Table 1 . The analysis of variance showed no significant difference $(p>0.05)$ both for the water and the air temperatures at the study stations. Edokpayi and Nkwoji (2007) recorded relatively uniform values for both surface water and air temperatures in the Lagos lagoon and attributed this to the conservative nature of this parameter in tropical waters. Temperature has been shown to be a less significant factor in lagoons and estuaries in the tropics (Ajao, 1990; Nkwoji et al., 2010).

The values obtained for dissolved oxygen in the wet season were relatively higher than in the dry season. This observation is in agreement with Ajao (1990). The high concentration in the wet season could be as a result of perturbation of water by rain and surface run-off prevalent in the season. Perturbation could actually result to the diffusion of atmospheric oxygen into the water consequently increasing the dissolved oxygen in the water. A higher level of dissolved oxygen recorded during the wet season could also be linked to floodwater dilution and reduced resident time of the polluted water as previously observed by Brown (1991) and Nkwoji et al., (2010). Areas of pronounced inputs of organic wastes such as Iddo I, Iddo II, Ogudu and Agboiyi study stations recorded low values of dissolved oxygen. This could be attributable to the consumption of the dissolved oxygen by aerobic microorganisms which biodegrade the organic wastes. The low level of dissolved oxygen observed in Iddo I study station was further exacerbated by the high level of oil and grease resulting from spills from illegal traders of these products. The oil and grease form a sheen and seal off the diffusion of atmospheric oxygen into the water body of this study station and thereby reducing the dissolved oxygen of the water. This observation agrees with Doherty et al., (2013) on the negative effects of oil and grease on aquatic fauna. 
Study stations like Iddo I, Iddo II, Ogudu and Agboiyi with very low DO values recorded high values of BOD. The relationship that existed between DO and BOD at the study stations was generally an inverse relationship. It is the dissolved oxygen in the water that is being depleted or utilized by the microorganisms and hence, the elevated biochemical oxygen demand value. It therefore, entails that a high value of biochemical oxygen demand will imply a low level dissolved oxygen and vice-versa. Agboyi study station with very low dissolved oxygen value recorded the highest BOD value of $42 \mathrm{mg} / \mathrm{L}$.
In general, temporal variation in the physicochemical characteristics of water in the study area is largely controlled by rainfall pattern, as the influx of fresh water alters the physic-chemistry of the water while the run-off introduces new materials into the water body. The spatial variation in the physicochemical characteristics of water in the study area is largely influenced by proximity of the study station to Harbour as well as the pollution sources and type of the study station. Such parameters as salinity, conductivity and TDS increase with nearness of the study station to the Harbour, while different pollution sources introduce different pollutants which exhibit their peculiar impact on the physico-chemistry of the water of the study station. 
Table 1: A Summary of the Physico-Chemical Characteristics of the Water in the Study Area

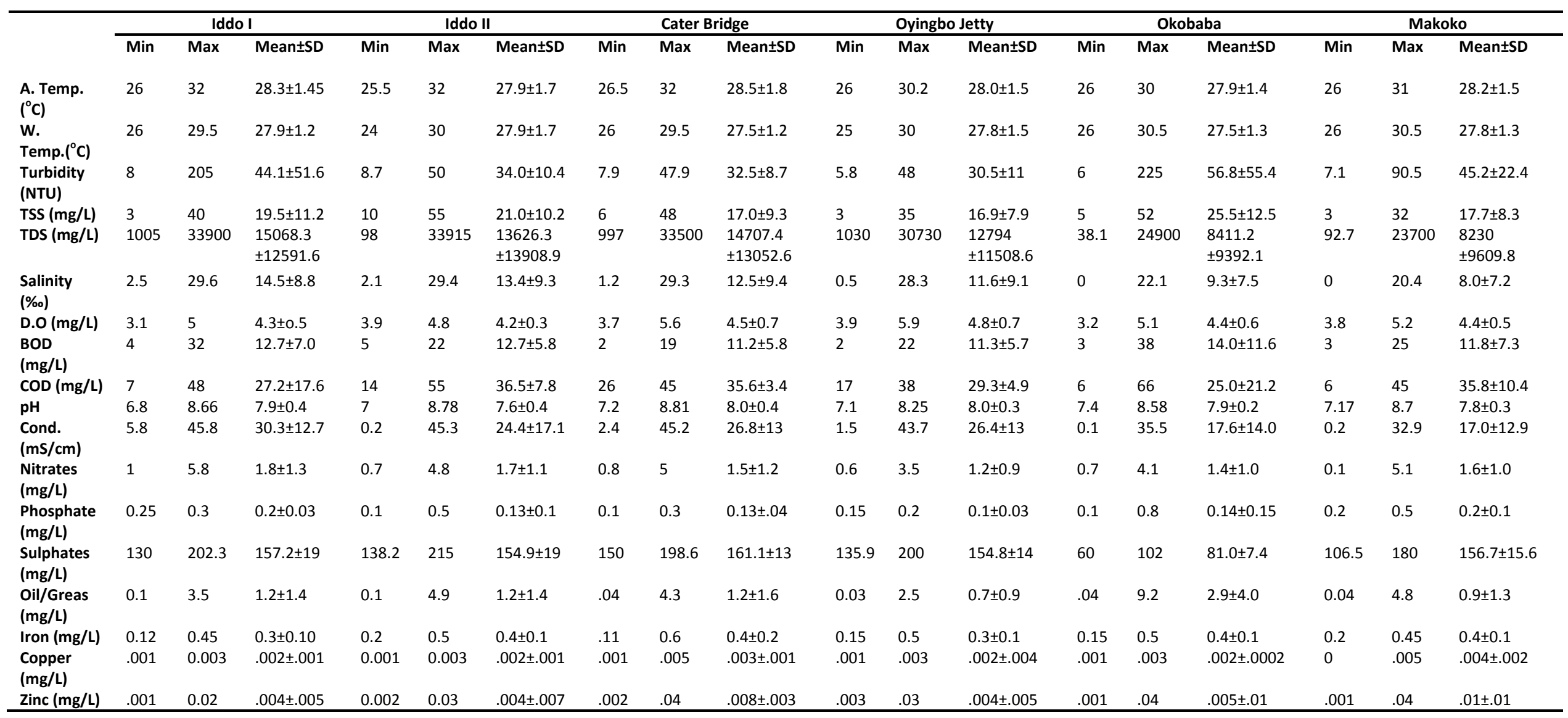


Table 1: Cont. A Summary of the Physico-Chemical Characteristics of Water in the Study Area

\begin{tabular}{|c|c|c|c|c|c|c|c|c|c|c|c|c|c|c|c|c|c|c|}
\hline & \multicolumn{3}{|c|}{ Abule Agege } & \multicolumn{3}{|c|}{ Unilag Front } & \multicolumn{3}{|c|}{ Eledu Creek } & \multicolumn{3}{|c|}{ Mid-lagoon } & \multicolumn{3}{|c|}{ Ogudu } & \multicolumn{3}{|c|}{ Agboiyi } \\
\hline & Min & Max & Mean \pm SD & Min & Max & Mean $\pm S D$ & Min & Max & Mean $\pm S D$ & Min & Max & Mean $\pm S D$ & Min & Max & Mean $\pm S D$ & Min & Max & Mean $\pm S D$ \\
\hline A. Temp. $\left({ }^{\circ} \mathrm{C}\right)$ & 26.5 & 32 & $28.3 \pm 1.7$ & 26 & 31.3 & $28.2 \pm 1.7$ & 27 & 32.6 & $28.8 \pm 1.7$ & 26 & 30.8 & $28.4 \pm 1.5$ & 26.5 & 32.8 & $28.6 \pm 2.0$ & 26 & 32.7 & $28.6 \pm 2.0$ \\
\hline W. Temp. $\left({ }^{\circ} \mathrm{C}\right)$ & 26 & 31 & $28.2 \pm 1.4$ & 25 & 31 & $27.9 \pm 2.2$ & 25 & 31 & $27.9 \pm 1.8$ & 25 & 30 & $27.7 \pm 1.6$ & 26 & 31.5 & $28.1 \pm 1.7$ & 25 & 30 & $27.6 \pm 1.7$ \\
\hline Turbidity (NTU) & 5.2 & 72 & $29.3 \pm 18.2$ & 5.5 & 58.3 & $28.4 \pm 17.1$ & 13.8 & 155 & $37.1 \pm 29.7$ & 5.5 & 52 & $23.7 \pm 10.3$ & 26 & 212 & $79.7 \pm 54.9$ & 25 & 125 & $60 \pm 37.9$ \\
\hline TSS (mg/L) & 1 & 28 & $12.0 \pm 7.9$ & 10 & 25 & $16.2 \pm 4.9$ & 10 & 31.9 & $17.0 \pm 6.7$ & 2 & 28.5 & $12.7 \pm 8.2$ & 2 & 58 & $25.6 \pm 16.7$ & 14 & 74 & $28.2 \pm 16.7$ \\
\hline TDS (mg/L) & 93.9 & 25380 & $\begin{array}{l}5470.8 \\
\pm 7485.4\end{array}$ & 103.5 & 24800 & $\begin{array}{l}9563.5 \\
\pm 10191.0\end{array}$ & 40.5 & 22850 & $\begin{array}{l}8875.4 \\
\pm 9802.2\end{array}$ & 1223 & 29100 & $\begin{array}{l}13613 \\
\pm 11562.6\end{array}$ & 50.1 & 24770 & $\begin{array}{l}7104.8 \\
\pm 9262.6\end{array}$ & 50 & 22700 & $\begin{array}{l}7604.5 \\
\pm 9165.8\end{array}$ \\
\hline Salinity (\%o) & 0 & 25.8 & $8.6 \pm 8.2$ & 0 & 20.2 & $8.7 \pm 8.7$ & 0 & 18.6 & $7.4 \pm 8.1$ & 2 & 22.2 & $11.1 \pm 8.1$ & 0 & 5.85 & $2.1 \pm 2.0$ & 0 & 8.8 & $2.8 \pm 2.9$ \\
\hline D.O (mg/L) & 4 & 5.8 & $5.1 \pm 0.5$ & 4 & 5.2 & $4.6 \pm 0.4$ & 3.9 & 5.3 & $4.6 \pm 0.5$ & 4.4 & 5.6 & $5.0 \pm 0.3$ & 3 & 4.8 & $3.7 \pm 0.4$ & 2.8 & 4.2 & $3.6 \pm 0.4$ \\
\hline $\mathrm{BOD}(\mathrm{mg} / \mathrm{L})$ & 3 & 18 & $10.3 \pm 5.0$ & 4 & 20 & $10.9 \pm 4.8$ & 5.4 & 19 & $11.0 \pm 4.6$ & 2.2 & 18 & $11.6 \pm 4.5$ & 7 & 32.9 & $19.0 \pm 7.6$ & 8 & 42 & $19.9 \pm 9.9$ \\
\hline $\mathrm{COD}(\mathrm{mg} / \mathrm{L})$ & 4 & 50 & $28.2 \pm 14.6$ & 24 & 33 & $29.0 \pm 2.19$ & 28 & 36 & $31.5 \pm 2.8$ & 13.5 & 65 & $27.0 \pm 8.7$ & 12 & 60 & $41.2 \pm 14.0$ & 22 & 50 & $37.6 \pm 11.6$ \\
\hline $\mathrm{pH}$ & 7.1 & 9.72 & $7.9 \pm 0.5$ & 7.1 & 8.3 & $7.9 \pm 0.3$ & 7.1 & 8.7 & $8.2 \pm 0.3$ & 7.14 & 8.03 & $7.8 \pm 0.3$ & 7.1 & 8.8 & $7.9 \pm 0.4$ & 7.2 & 8.59 & $7.9 \pm 0.3$ \\
\hline Cond. (mS/cm) & 0.2 & 45.5 & $19.0 \pm 15.1$ & 0.3 & 35.5 & $18.1 \pm 13.4$ & 0.1 & 33.9 & $15.8 \pm 12.5$ & 4.3 & 48.9 & $27.4 \pm 11.5$ & 0.1 & 30.2 & $8.2 \pm 8.7$ & 0.4 & 28 & $10.5 \pm 8.7$ \\
\hline Nitrates (mg/L) & 0.3 & 3.4 & $0.9 \pm 0.8$ & 0.5 & 5 & $1.2 \pm 1.1$ & 0.7 & 5.2 & $1.4 \pm 1.1$ & 0.1 & 4.2 & $0.9 \pm 1.1$ & 0.9 & 6 & $2.3 \pm 1.4$ & 1 & 7.6 & $2.5 \pm 1.5$ \\
\hline $\begin{array}{l}\text { Phosphate } \\
\text { (mg/L) }\end{array}$ & 0.1 & 0.8 & $0.2 \pm 0.2$ & 0.03 & 0.2 & $0.1 \pm 0.05$ & .04 & 0.9 & $0.4 \pm 0.4$ & 0.1 & 0.3 & $0.1 \pm 0.04$ & 0.1 & 2.2 & $0.9 \pm 0.8$ & 0.1 & 2.9 & $1.5 \pm 1.3$ \\
\hline $\begin{array}{l}\text { Sulphates } \\
\text { (mg/L) }\end{array}$ & 7.2 & 175.2 & $64.5 \pm 57.5$ & 49.5 & 160.5 & $94.8 \pm 43.5$ & 60.7 & 148.7 & $103.1 \pm 34$ & 4.5 & 160.2 & $83.4 \pm 71.7$ & 106 & 172.5 & $131.0 \pm 19$ & 128 & 220 & $154.3 \pm 22$ \\
\hline $\begin{array}{l}\text { Oil/Greas } \\
\text { (mg/L) }\end{array}$ & 0.03 & 4.5 & $1.4 \pm 1.8$ & 0.1 & 2.8 & $0.9 \pm 1.1$ & 0.1 & 2.8 & $0.7 \pm 0.8$ & .02 & 3 & $0.8 \pm 1.1$ & 0.04 & 5.4 & $1.6 \pm 1.7$ & 0.05 & 4.9 & $1.2 \pm 1.5$ \\
\hline Iron (mg/L) & 0.2 & 0.65 & $0.3 \pm 1.1$ & 0.15 & 0.3 & $0.2 \pm 0.1$ & 0.2 & 0.3 & $0.2 \pm 0.1$ & 0.1 & 0.4 & $0.3 \pm 0.1$ & 0.15 & 0.5 & $0.31 \pm 0.1$ & .20 & 0.6 & $0.4 \pm 0.2$ \\
\hline Copper (mg/L) & .001 & 0.02 & $0.01 \pm 0.01$ & .001 & .003 & $.002 \pm .001$ & .001 & .003 & $.002 \pm .004$ & .001 & 0.003 & $.002 \pm .001$ & .001 & .005 & $.003 \pm .001$ & .001 & .005 & $.005 \pm .001$ \\
\hline Zinc $(\mathrm{mg} / \mathrm{L})$ & .001 & 0.15 & $0.1 \pm 0.1$ & .001 & .02 & $.005 \pm .01$ & .001 & .02 & $.004 \pm .004$ & .002 & 0.03 & $.01 \pm .01$ & .002 & 0.06 & $.01 \pm .03$ & .002 & .03 & $.01 \pm .01$ \\
\hline
\end{tabular}




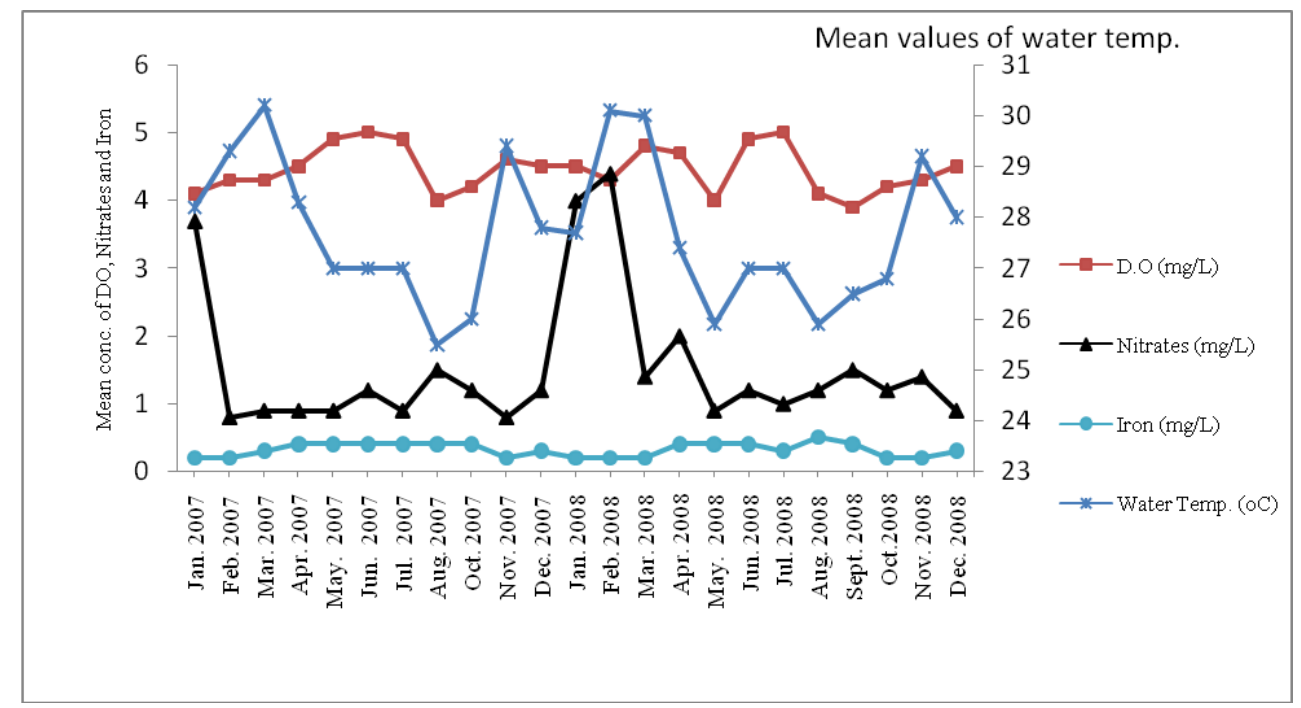

Fig 2: Monthly variation in the mean values of Water temp., D.O, Nitrates and Iron of the water samples

A summary of the benthic macroinvertebrates collected at the study stations is presented in Table 2 . A total of 3,159 individuals comprising three phyla, five classes, nineteen families and twenty-three species were recorded. Study stations with low dissolved oxygen values recorded higher number of polychaetes than the stations with relatively higher dissolved oxygen values. The biological indices showing the community structure of the benthic macroinvertebrates at the study stations are shown in Table 3.

Margalef's index of species richness ranged from 0.79 to 2.57 while Shannon-Wiener index ranged from 0.40 to 2.19 . Both indices were highest at Oyingbo Jetty monitoring station. The highest number of species was collected at this station. This could have accounted for high Margalef's and Shannon-Wiener indices, even when the station recorded comparatively low number of individuals.

Both abundance and diversity of the macrobenthic fauna at the study stations were very low compared to earlier studies (Ajao, 1990; Ajoa and Fagade, 1991; Brown and Oyenekan, 1998; Chukwu and Nwankwo, 2004).
The low numerical abundance and diversity are largely due to physical variability of the study area, sampling methodology, and the prevailing ecological conditions, including the state of contamination from anthropogenic sources of the study area at the time of study. According to Edokpayi and Nkwoji (2007) and Nkwoji et al., (2010), the western part of Lagos lagoon and its adjacent creeks are under stress resulting from pollution sources from both industrial and anthropogenic sources.

The sedentary nature of the benthic macroinvertebrates makes them very vulnerable to the impacts of the pollution (Ajao, 1990). However, some of the species have some adaptive features, both physiological and morphological, to hypoxia and these have given them some advantages and resulted to their relative abundance. The opportunistic nature of the nereid polychaetes could have attributed to the high dominance index in Iddo 2 monitoring station where these polychaetes were found in abundance. 
Table 2: A Summary of Total Benthic Macroinvertebrates Collected at the Study Stations in the Study Area for the Period of Study

\begin{tabular}{|c|c|c|c|c|c|c|c|c|c|c|c|c|c|}
\hline Benthic Taxa & Iddo I & Iddo II & $\begin{array}{l}\text { Carter } \\
\text { Bridge }\end{array}$ & $\begin{array}{l}\text { Oyingbo } \\
\text { Jetty }\end{array}$ & Okobaba & Makoko & $\begin{array}{l}\text { Abule- } \\
\text { Agege }\end{array}$ & $\begin{array}{l}\text { Unilag } \\
\text { lagoon }\end{array}$ & $\begin{array}{l}\text { Eledu } \\
\text { creek }\end{array}$ & $\begin{array}{l}\text { Mid- } \\
\text { lagoon }\end{array}$ & Ogudu & Agboiyi & Total \\
\hline \multicolumn{14}{|l|}{ Mollusca } \\
\hline Neritina senegalensis & - & - & - & - & - & - & - & 14 & & 3 & - & - & 17 \\
\hline Neritina glabrata & 1 & - & 1 & 11 & 41 & 14 & 357 & 28 & 8 & 51 & 1 & 3 & 516 \\
\hline Pachymelania aurita & 2 & - & 7 & 34 & 4 & 4 & 866 & 127 & 20 & 84 & 1 & 9 & 1156 \\
\hline Tympanotonus fuscatus & 6 & 1 & 7 & 13 & 53 & 14 & 13 & 98 & 46 & 66 & 7 & 8 & 332 \\
\hline T.fuscatus Var radula & 3 & - & 5 & 4 & 13 & 9 & 6 & 26 & 10 & 10 & - & 2 & 88 \\
\hline Thais haemostoma & - & - & - & - & - & - & - & - & - & 2 & - & - & 2 \\
\hline Mytilus perna & - & - & - & - & - & - & - & - & - & 3 & - & - & 3 \\
\hline Mytilus edulis & - & - & - & - & 2 & - & 14 & - & - & 40 & - & - & 56 \\
\hline Crassostrea gasar & - & - & - & - & - & - & 1 & - & 5 & - & - & 5 & 11 \\
\hline Dosinia isocarda & - & - & 3 & 5 & - & - & - & - & - & - & - & 3 & 11 \\
\hline Mactra glabrata & - & - & - & - & - & - & - & 1 & - & 5 & - & - & 6 \\
\hline Iphigenia rostrata & - & - & - & - & - & - & 9 & - & - & 5 & - & - & 14 \\
\hline Iphigenia truncata & 1 & - & 6 & 5 & 5 & 2 & 45 & 16 & 7 & 29 & - & 2 & 118 \\
\hline Tellina nymphalis & 4 & 2 & 3 & 32 & 18 & 1 & 19 & 31 & 7 & 17 & 1 & 9 & 144 \\
\hline Aloides trigona & 2 & 1 & 7 & 20 & 12 & 4 & 57 & 55 & 18 & 35 & 2 & 2 & 215 \\
\hline \multirow[t]{2}{*}{ Aloides sulcata } & - & - & - & 5 & 3 & - & 13 & 8 & 1 & 5 & - & - & 35 \\
\hline & 19 & 4 & 39 & 129 & 151 & 48 & 1400 & 404 & 122 & 355 & 12 & 43 & 2724 \\
\hline \multicolumn{14}{|l|}{ Annelida } \\
\hline Glycera sp & 2 & - & 1 & 1 & - & - & - & - & - & - & - & - & 4 \\
\hline Nephtys sp & - & - & - & 2 & - & - & - & - & - & - & - & - & 2 \\
\hline Nereis diversicolor & 37 & 40 & 6 & 23 & 3 & - & 1 & 4 & 2 & - & 45 & 18 & 179 \\
\hline \multirow{3}{*}{$\begin{array}{l}\text { Tapitella capitata } \\
\text { Tubp }\end{array}$} & - & - & - & 3 & 4 & - & - & - & - & - & 32 & 38 & 77 \\
\hline & - & - & - & - & - & - & - & - & - & - & 1 & 8 & 9 \\
\hline & 39 & 40 & 7 & 29 & 7 & $\mathbf{0}$ & 1 & 4 & 2 & $\mathbf{0}$ & 78 & 64 & 271 \\
\hline \multicolumn{14}{|l|}{ Arthropoda } \\
\hline Penaeus notialis & - & - & - & 2 & - & - & - & - & - & - & - & - & 2 \\
\hline Clibinarius africanus & - & - & - & - & - & - & 50 & 85 & 22 & - & - & - & 157 \\
\hline \multirow{2}{*}{ Sersama huzardi } & 4 & - & - & 1 & - & - & - & - & - & - & - & - & 5 \\
\hline & 4 & 0 & $\mathbf{0}$ & 3 & 0 & $\mathbf{0}$ & 50 & 85 & 22 & $\mathbf{0}$ & 0 & $\mathbf{0}$ & 164 \\
\hline TOTAL & 62 & 44 & 46 & 161 & 158 & 48 & 1451 & 493 & 146 & 355 & 90 & 107 & 3159 \\
\hline
\end{tabular}


Table 3: Biodiversity Indices of Benthic Macroinvertebrates in the twelve Study Stations

\begin{tabular}{|c|c|c|c|c|c|c|c|c|c|c|c|c|}
\hline & 훙 & 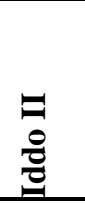 & 苞 & 总 & $\begin{array}{l}\frac{a}{0} \\
\frac{0}{0} \\
\frac{0}{0} \\
\frac{1}{0}\end{array}$ & $\begin{array}{l}\frac{0}{0} \\
\frac{\pi}{\pi} \\
\sum\end{array}$ & 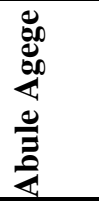 & 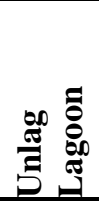 & 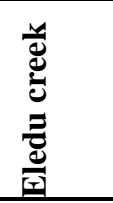 & 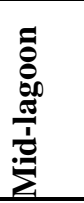 & 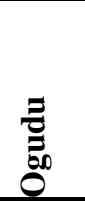 & 递 \\
\hline Taxa $S$ & 9 & 4 & 9 & 14 & 10 & 6 & 12 & 11 & 10 & 13 & 8 & 11 \\
\hline Individuals & 62 & 44 & 46 & 159 & 158 & 48 & 1451 & 493 & 146 & 355 & 100 & 107 \\
\hline Dominance & 0.39 & 0.83 & 0.16 & 0.14 & 0.26 & 0.33 & 0.42 & 0.18 & 0.21 & 0.15 & 0.41 & 0.19 \\
\hline Shannon & 1.41 & 0.40 & 1.98 & 2.19 & 1.66 & 1.34 & 1.25 & 1.91 & 1.84 & 2.06 & 1.14 & 1.99 \\
\hline Simpson & 0.61 & 0.17 & 0.84 & 0.86 & 0.74 & 0.67 & 0.58 & 0.82 & 0.79 & 0.85 & 0.59 & 0.81 \\
\hline Evenness & 0.45 & 0.37 & 0.80 & 0.63 & 0.53 & 0.64 & 0.29 & 0.62 & 0.63 & 0.61 & 0.39 & 0.67 \\
\hline Margalef & 1.94 & 0.79 & 2.09 & 2.57 & 1.78 & 1.29 & 1.51 & 1.61 & 1.81 & 2.04 & 1.52 & 2.14 \\
\hline Equitability & 0.64 & 0.29 & 0.90 & 0.83 & 0.72 & 0.75 & 0.50 & 0.80 & 0.80 & 0.80 & 0.55 & 0.83 \\
\hline
\end{tabular}

Conclusion:

Iddo II has the least number of species and individual or ganisms. This monitoring station shows

the highest value of the dominance index. The station was dominated by the polychaetes and this could be attributed to their adaptation to hypoxia. The station is the point source of untreated sewage dump with its attendant low dissolved resulting from the biodegradation of the sewage. Other benthic macroinvertebrates were almost virtually missing at this station and this underscores the impact that hypoxia could have on the community structure of these benthic macroinvertebrates. There was general low biodiversity indicating the stressed nature of the study area as a result of highly depleted dissolved oxygen.

\section{REFERENCES}

Adeniyi, M. T. (1980). Microbial decomposition of faeces in Lagos lagoon. Ph.D Thesis, University of Lagos. 102pp

Ajao. E.A. (1990). The influence of domestic and industrial effluents on populations of sessile and benthic organisms in Lagos lagoon. Ph.D Thesis. University of Ibadan, Nigeria. 413pp

Ajao, E. A.and Fagade, S. O. (1990) The ecology of Capitella capitata in Lagos lagoon, Nigeria. Archive for Hydrobiolog., 120(2): 229-239

Ajao, E. A. and Fagade, S. O. (1991). Study of the sediments and communities in Lagos Lagoon, Nigeria. Oil and Chemical Pollution. Elsevier Science Publishers Ltd., England. 75-117.

Akpata, T.V.I. and Ekundayo, J. A. (1978) Faecal pollution of the Lagos lagoon. Nigerian Journal of Science. 12(1 and2):39-49
APHA. (American Public Health Association). (1998). Standard Methods for the Examination of Water and Waste Water. 20th ed. APHA New York, 1270 pp.

Brown, C.A. (1991). Community structure and secondary production of benthic macrofauna of Lagos lagoon and Harbour. M.Phil. Thesis, University of Lagos, Nigeria. 359pp.

Brown, C. A. and Oyenekan, J. A. (1998). Temporal variability in the structure of benthic macrofauna communities of the Lagos lagoon and harbour, Nigeria. Polskie Archiwum Hydrobiologii. 45(1): 45-54

Brown, C. A. (2000). The diversity and density of macrobenthic fauna in the western part of the Lagos Lagoon, South-West, Nigeria. Ph.D Thesis, University of Lagos, Lagos, Nigeria. 346pp

Chukwu, L. O. and Nwankwo, D. I. (2004) The impact of land based pollution on the hydro-chemistry and macrobenthic community of a tropical West African Creek. The Ekologia. 2(1-2): 1- 9

Edokpayi, C. A and Nkwoji, J. A. (2007). Annual changes in the physico-chemical and macrobenthic invertebrate characteristics of the Lagos lagoon sewage dump site at Iddo, Southern Nigeria. Ecology, Environment. and Conservation 13(1): 13-18

Doherty,V, Kanife, U. C., Okeleye, B. T. (2013).

Toxicological Effects and Histopathology of African Ca tfish (Clarias gariepinus) Exposed to Water Soluble Fractions of Diesel and Kerosene Current Advances in Environmental Science, 1(2), 16-21 
Ekundayo, J. A. (1977). Environmental consequences of pollution of the Lagos lagoon. Bulletin of Science Association of Nigeria, 3(2): 290-299

F.A.O. (1969) Fisheries Survey in the Western and mid-Western Regions of Nigeria. FAO/sf.74/NIR6. 142pp.

Nkwoji, J. A., Yakub A., Ajani, G. E., Balogun, K. J., Renner, K.O.,Igbo, J. K., Ariyo, A. A and Bello, B. O. (2010). Seasonal Variations in the Water Chemistry and Benthic Macroinvertebrates of a South Western Lagoon, Lagos, Nigeria. Journal of American Science 6(3):85- 92.

Nwankwo, D. I. and Akisoji, A. (1992). Epiphyte community on water hyacinth Eichhornia crassipes (Mart.).Solms. in coastal waters of southwestern Nigeria. Archive for Hydrobiolog., 124(4): 501-511

Nwankwo, D. I. (1994). Hydrochemical properties and bottom-dwelling diatoms of a Lagos lagoon sewage disposal site. Polskie Archiwum Hydrobiologii, 41(1): 35-47

Nystrom, P., Bronmark, C. and Graneli, W. (1996) Patterns in benthic food webs - a role for omnivorous crayfish. Freshwater Biology. 36: 631-646

Ogbeibu, A.E. (2005). Biostatistics: A practical approach to research and data handling. Mindex Publishing Co. Ltd., Benin, Nigeria. 264pp,
Olaniyan C. I. O. (1968) An Introduction to West African Animal Ecology. London \& Ibadan: Heinemann. 167 pp.

Onyema, I .C., Nkwoji, ,J. A. and Eruteya, O.J.(2009). The Water Chemistry and Plankton Dynamics of a Tropical High Energy Erosion Beach in Lagos Journal of American Science. 5(8):13-24

Oyenekan, J. A. (1983). Reproduction and population dynamics of Capitella capitata. Archive for Hydrobiology 98(1): 115-126

Oyenekan, J. A. (1987). Benthic macrofauna of Lagos lagoon, Nigeria. Nigeria Journal of Science. 20: $45-51$

Oyenekan, J. A. (1989) The ecology of the genus Pachymelania in Lagos lagoon. Archive for Hydrobiology, 86 (4): 515-522

Stockley, R. A., Oxford, G. S. and Ormond, R.F.G. (1998). Do invertebrates matter? Detrital processing in the River Swale-Ouse. Science of the Total Environment. 210: 427-435.

Yankson, K. and Kendall, M. A. (2001). A student's guide to the seashore of West Africa: Marine biodiversity capacity building in the West African sub-region. 132pp

Yoloye, V. and Adegoke, O. S. (1977). A new species of Neritina (Archaeogastroda, Neritidae) from the Lagos lagoon. Malacologia. 16(1): 303 - 309

Zar, J. H. (1984). Biostatistical Analysis, 2 edn. New Jersey: Prentice-Hall. 718 pp 